\title{
THE RELATIONSHIP BETWEEN BONE MINERAL DENSITY AND HIGH-DOSE SHORT-TERM CORTICOSTEROID THERAPY IN PATIENTS WITH MULTIPLE SCLEROSIS
}

\author{
Sirinocak Bekdik Pinar, ${ }^{1}$ Eskut Neslihan, ${ }^{2}$ Sener Ufuk, ${ }^{3}$ Zorlu Yasar ${ }^{3}$ \\ ${ }^{1}$ University of Health Sciences, Derince Training and Research Hospital, \\ Department of Neurology, Kocaeli, Turkey \\ ${ }^{2}$ University of Health Sciences, Izmir Bozyaka Training and Research Hospital, \\ Department of Neurology, Izmir, Turkey \\ ${ }^{3}$ University of Health Sciences, Izmir Tepecik Training and Research Hospital, \\ Department of Neurology, Izmir, Turkey
}

Primljen/Received 11. 07. 2020. god.

Abstract: Introduction: Previous studies were reported that osteoporosis and bone fracture occurs more frequently among Multiple sclerosis patients than the general population. The aim of this study to investigate the affects of total doses of short-term, high dose corticosteroids on bone mineral density and other affecting factors for bone mineral density in Relapsing-remitting type Multiple Sclerosis patients.

Material and methods: Fifty-four patients (37 females, 17 males) with relapsing-remitting type Multiple Sclerosis who filled the diagnostic criteria according to McDonald criteria were included in the study. Femoral and lumbar bone mineral density were measured using dual energy X-ray absorptiometry. Expanded Disability Status Scale, disease duration, number of attacks, cumulative corticosteroid dose were recorded. Serum calcium, potassium, phosphorus, vitamin D, parathormone and osteocalcin levels were measured. Patients were divided into two groups: patients who have received at least $20 \mathrm{~g}$ intravenous metilprednisolone (Group I) and patients who have received less than $20 \mathrm{~g}$ intravenous metilprednisolone (Group II). We analysed association between cumulative corticosteroid dose and each parameters.

Results: Osteopenia was present in $46.2 \%$ and osteoporosis in $5.5 \%$ of the study population according to femoral neck bone mineral density. Femoral bone mineral density was significantly lower among patients. There was no correlation between cumulative dose of corticosteroid and bone mineral density.

Conclusion: Low bone mineral density and osteoporosis are common in Multiple sclerosis patients.
Prihvaćen/Accepted 11. 09. 2020. god.

High-dose steroid therapy is not be the primary cause of osteoporosis in patients with multiple sclerosis.

Key words: Multiple sclerosis, bone mineral density, vitamin D.

\section{INTRODUCTION}

Multiple sclerosis (MS) is a chronic, progressive demyelinating disease of the central nervous system that causes significant disability in the young population. Previous studies were reported that osteoporosis and bone fracture occurs more frequently among MS patients than the general population, probably as a result of reduced mobility, vitamin D deficiency and exposure to corticosteroid (CS) (1-5). Oral CS treatment leads to a reduction in bone mineral density (BMD) and a rapid (within 3 to 6 months) increase in the risk of fracture during the treatment period (6). In Relapsing-Remitting MS (RRMS) patients, short-term intravenous high-dose methylprednisolone (IVMP $1 \mathrm{~g} /$ day) are commonly used during acute relapse (7). It is well known effect on BMD of chronic CS exposure, but, the effect of short-term, high-dose therapy on BMD are still unclear.

The aim of this study to investigate the affects of cumulative IVMP dose and other factors on BMD in RRMS patients.

\section{PATIENTS AND METHODS}

This study was conducted in multiple sclerosis outpatient clinic of a training and research hospital, 
University of Sciences, Tepecik Training and Research Hospital, between June 2009 and December 2009. Fifty-four patients with RRMS (37 female and 17 male) diagnosed according to the McDonald criteria, aged 20 to 56 years were included in this study. All procedures performed in study were in accordance with the ethical standards of the institutional research committee and with the Helsinki declaration. Patients with a disease (hyperthyroidism, rheumatoid arthritis etc.) or medication use (hormone replacement, oral contraceptive pill etc.) that might affect on BMD were excluded from the study. None of female women patients is menopause. All patients were in remission and had not received CSs in the last three months due to relapse. Clinical data and the glucocorticoids (GC) doses were obtained by carefully searching medical records. Expanded Disability Status Scale (EDSS), disease duration, number of attacks, cumulative CS dose were recorded for all patients.

Serum calcium, potassium, phosphorus, vitamin $\mathrm{D}$, parathormone $(\mathrm{PTH})$ and osteocalcin levels were measured both patients. Laboratory tests included serum concentrations of vitamin $\mathrm{D}$, parathyroid hormone and osteocalcin. 25 hydroxyvitamin D3 (25-OH-vitamin D3) isoform was measured. 25-OH-vitamin D3 concentrations and osteocalcin levels were assessed by a chemiluminescence immunoassay. 25-OH-vitamin D3 concentrations was assessed with Diasorin (Diasorin Inc. Northwestern Avestillwater, USA) kit and osteocalcin levels was assessed with Siemens Healthcare Diagnostics (Siemens Diagnostics Inc. Los Angeles, USA) kit. Parathyroid hormone levels were assessed using routine laboratory methods (normal range: 10-69 $\mathrm{pg} / \mathrm{ml}$ ). The 25-OH-vitamin D3 concentrations, parathyroid hormone and osteocalcin levels in patients were compared to normal reference range. Laboratory referential values for 25-OH-vitamin D3 levels in the serum ranged between $30-80 \mathrm{ng} / \mathrm{ml}$ and osteocalcin levels in the serum ranged between $2-21 \mathrm{ng} / \mathrm{ml}$.

Dual energy X-ray absorptiometry (DEXA; Hologic QDR- $4500^{\circ} \mathrm{C}$ ) was used to measure BMD values at the lumbar vertebrae (L2-L4 in the AP projection) and in the proximal femur (femoral neck), in addition to $\mathrm{T}$ and $\mathrm{Z}$ scores. T-score is used to make a diagnosis of normal bone density, osteoporosis, or osteopenia according to the World Health Organization (WHO) criteria. T-score of $>1.0$ was considered normal. A T-score between -1.0 and -2.5 was interpreted as osteopenia and a T-score of $<-2.5$ indicated osteoporosis (8).

According to the total dose of IVMP received during the illness, patients included in the study were divided into two groups: patients who have received at least $20 \mathrm{~g}$ IVMP (Group I) and patients who have received less than $20 \mathrm{~g}$ IVMP (Group II).
We assessed whether there was any difference in BMD and other parameters between groups.

\section{STATISTICAL ANALYSIS}

Statistical evaluations were made with the SPSS 15.0 program. Student's t-test, the Mann-Whitney U test and Pearson correlation coefficient were used in the comparison. Values of $p<0.05$ were considered significant.

\section{RESULTS}

Descriptive characteristics and densitometry measurement results of all patients were summarized in Table 1. Mean age of the all RRMS patients was $37.68 \pm$ 9.31 (20-56) years, mean disease duration was $10.32 \pm$ $6.10(2-27)$ years and EDSS was $1.49 \pm 0.73(0-3.5)$. $68.5 \%$ of the patients were women. All of the patients were ambulatory (EDSS $<3.5$ ). All patients had normal range of serum calcium. Mean vitamin D level was $14.4 \pm 6.96 \mathrm{ng} / \mathrm{ml}(2-28.9) .77 .7 \%$ of the patients had vitamin D level below normal level (vitamin D deficient). Mean osteocalcin level was $4.54 \pm 3.16 .77 .7 \%$ of the patients had normal osteocalcin levels.

When we classify BMD measurements as normal, osteopenia and osteoporosis according to WHO criteria, femoral neck BMD was observed as normal in 26 (48.8\%) patients, osteopenia in $25(46.2 \%)$ patients, and osteoporosis in $3(5,5 \%)$ patients. And, lumbar vertebrae BMD was observed as normal in 29 (53.7\%) patients, osteopenia in 19 (35.1\%) patients and osteoporosis in $6(11.1 \%)$ patients. Mean BMD on femur neck $(0.78 \pm 0.14)$ was lower than lumbar vertebrae $\operatorname{BMD}(0.95 \pm 0.14)(\mathrm{p}>0.05)$. Overall rates of osteopenia and osteoporosis according to femoral neck in RRMS patients were $46.2 \%$ and $5.5 \%$ respectively. In all patients, no statistically significant difference was found between BMD and other parameters including disease duration, EDSS and vitamin D level (Table 1).

There were 32 patients in group I and 22 patients in group II. No statistically significant differences were found in terms of sex, age, EDSS, disease duration, level of parathormon, vitamin $D$ and osteocalcin, lumbar vertebrae $\mathrm{T}$ and $\mathrm{Z}$ score, femur neck $\mathrm{T}$ and $\mathrm{Z}$ score, lumbar vertebrae BMD and femur neck BMD between groups. There was a significant difference between the groups in terms of the number of attacks. Patients who received more than $20 \mathrm{gr}$ of pulse IVMP had more attacks (p: 0.000) (Table 1).

There was no statistically significant difference was determined in terms of mean osteocalcin and PTH levels between the groups (p: 0,22 and p: 0,31).When osteocalcin levels of the groups were compared in 
Table 1. Comparison of parameters between groups

\begin{tabular}{|c|c|c|c|c|}
\hline & Total & Group I & Group II & $\mathbf{P}$ \\
\hline Sex (Female/male) & $38 / 16$ & $21 / 11$ & $17 / 5$ & 0.54 \\
\hline Age (mean \pm SD) (year) & $37.68 \pm 9.31$ & $38.73 \pm 10.02$ & $36.23 \pm 8.37$ & 0.20 \\
\hline Disease duration (year) & $10.32 \pm 6.10$ & $9.91 \pm 6.16$ & $11.50 \pm 4.51$ & 0.10 \\
\hline Relaps number $($ mean $\pm \mathrm{SD})$ & $4.77 \pm 2.70$ & $3.88 \pm 2.77$ & $6.18 \pm 1.99$ & 0.00 \\
\hline EDSS $($ mean \pm SD) & $1.49 \pm 0.73$ & $1.48 \pm 0.74$ & $1.52 \pm 0.75$ & 0.64 \\
\hline PTH $($ mean $\pm \mathrm{SD}) \mathrm{pg} / \mathrm{mL}$ & $56.49 \pm 25.37$ & $61.35 \pm 26.12$ & $49.74 \pm 23.53$ & 0.31 \\
\hline Osteocalcin (mean $\pm \mathrm{SD}$ ) $\mathrm{ng} / \mathrm{ml}$ & $4.54 \pm 3.16$ & $4.67 \pm 2.81$ & $4.26 \pm 3.73$ & 0.22 \\
\hline Vitamin D (25 (OH) ) (mean \pm SD) $\mathrm{ng} / \mathrm{ml}$ & $14.4 \pm 6.96$ & $14.23 \pm 6,64$ & $14.45 \pm 7.65$ & 0.91 \\
\hline Lomber vertebrae $\mathbf{T}$ score $($ mean $\pm \mathrm{SD})$ & $-1.02 \pm 1.25$ & $-1.07 \pm 1.16$ & $-0.89 \pm 1.39$ & 0.82 \\
\hline Lomber vertebrae $\mathbf{Z}$ score (mean $\pm \mathrm{SD}$ ) & $-0.79 \pm 1.21$ & $-0.83 \pm 1.12$ & $-0.65 \pm 1.34$ & 0.29 \\
\hline Femur neck $\mathbf{T}$ score $($ mean $\pm \mathrm{SD})$ & $-0.99 \pm 1.03$ & $-0.94 \pm 0.95$ & $-1.05 \pm 1.18$ & 0.80 \\
\hline Femur neck $\mathbf{Z}$ score $($ mean $\pm \mathrm{SD})$ & $-0.71 \pm 0.94$ & $-0.66 \pm 0.85$ & $-0.76 \pm 1.08$ & 0.65 \\
\hline Lomber vertebra BMD $($ mean $\pm \mathrm{SD}) \mathrm{g} / \mathrm{cm}^{2}$ & $0.95 \pm 0.14$ & $0.95 \pm 0.13$ & $0.95 \pm 0.15$ & 1.00 \\
\hline Femur neck BMD $($ mean $\pm \mathrm{SD}) \mathrm{g} / \mathrm{cm}^{2}$ & $0.78 \pm 0.14$ & $0.79 \pm 0.12$ & $0.77 \pm 0.16$ & 0.78 \\
\hline
\end{tabular}

Table 2. Descriptive characteristics female and male MS patients

\begin{tabular}{|l|c|c|c|c|}
\hline & $\begin{array}{c}\text { Total } \\
(\text { mean } \pm \text { SD) }\end{array}$ & $\begin{array}{c}\text { Male } \\
(\text { mean } \pm \text { SD) }\end{array}$ & $\begin{array}{c}\text { Female } \\
(\text { mean } \pm \text { SD) }\end{array}$ & p \\
\hline Age (year) & $37.68 \pm 9.31$ & $37.23 \pm 10.11$ & $37.87 \pm 9.08$ & 0.81 \\
\hline MS disease duration $($ year) & $10.32 \pm 6.10$ & $8.59 \pm 6.15$ & $11.08 \pm 6.00$ & 0.11 \\
\hline Relaps number & $4.77 \pm 2.70$ & $4.71 \pm 3.48$ & $4.80 \pm 2.34$ & 0.63 \\
\hline EDSS & $1.49 \pm 0.73$ & $1.26 \pm 0.71$ & $1.59 \pm 0.73$ & 0.11 \\
\hline PTH $\mathrm{pg} / \mathrm{mL}$ & $56.49 \pm 25.37$ & $56.47 \pm 21.11$ & $56.49 \pm 27.27$ & 0.65 \\
\hline Osteocalcin $\mathrm{ng} / \mathrm{ml}$ & $4.54 \pm 3.16$ & $5.32 \pm 2.63$ & $4.19 \pm 3.34$ & 0.06 \\
\hline Vitamin D $(\mathbf{2 5}(\mathbf{O H})$ )ng/ml & $14.4 \pm 6.96$ & $18.75 \pm 5.64$ & $12.53 \pm 6.69$ & $\mathbf{0 . 0 0 2}$ \\
\hline Lomber vertebra T score & $-1.02 \pm 1.25$ & $-1.74 \pm 1.31$ & $-0.70 \pm 1.09$ & $\mathbf{0 . 0 0 3}$ \\
\hline Lomber vertebra Z score & $-0.79 \pm 1.21$ & $-1.61 \pm 1.24$ & $-0.42 \pm 1.02$ & $\mathbf{0 . 0 0}$ \\
\hline Femur neck T score & $-0.99 \pm 1.03$ & $-1.20 \pm 2.63$ & $-0.91 \pm 3.34$ & 0.34 \\
\hline Femur neck Z score & $-0.71 \pm 0.94$ & $-0.81 \pm 0.67$ & $-0.67 \pm 1.04$ & 0.60 \\
\hline Lomber vertebra BMD $\mathrm{g} / \mathrm{cm}^{2}$ & $0.95 \pm 0.14$ & $0.90 \pm 0.14$ & $0.97 \pm 0.13$ & 0.62 \\
\hline Femur neck BMD $\mathrm{g} / \mathrm{cm}^{2}$ & $0.78 \pm 0.14$ & $0.79 \pm 0.13$ & $0.78 \pm 0.14$ & 0.83 \\
\hline
\end{tabular}

BMD lumbar vertebrae measurements, osteocalcin levels of osteoporosis patients were statistically higher than in the normal patients (p: 0.01).

When the patients were classified according to gender, the lumbar vertebrae $Z$ score (p: 0.00) and T score (p: 0.003) of male patients was lower than female patients. No statistically significant difference was found between genders in other parameters (Table 2).

\section{DISCUSSION and CONCLUSION}

Our results showed a higher rate of osteoporosis and osteopenia (5.5\%) and osteopenia (46.2\%) in MS patients compared with the patient population with inflammatory bowel diseases (9). Lower BMD at femoral neck and lumbar vertebrae was present in $51.8 \%$ and $46.3 \%$ of the patients respectively. In previous studies, osteopenia was documented in $36.1 \%-80 \%$ patients with MS and osteoporosis in 4.7\%-37.5\% (10-18). It has been reported that osteopenia and osteoporosis are more common in the femoral neck compared to the lumbar spine in MS $(5,19)$. We did not found difference BMD loss between femoral neck and lumbar vertebrae.

The studies investigating the effect of IVMP therapy on BMD in MS patients reported conflicting re- 
sults. Some authors have reported a negative association between cumulative pulse corticosteroid dosage and $\operatorname{BMD}(17,20,21)$. Huang et al. explained that high-dose, short-term IVMP treatment is effective in accelerating sudden and permanent decreases in bone formation and a rapid and temporary increase in bone resorption (20). However, in our study and some others reported no significant relationship between cumulative pulse CS dose and $\operatorname{BMD}(5,16,18)$. Similarly, Olson et al. reported reduced BMD compared to a large cohort of MS patients in Denmark and an age-appropriate reference population, but they found no significant association between glucocorticoids (GC) dose (13).

The previous studies have reported negative correlation between BMD and EDSS (11, 15, 16, 18, 22, $23)$. In our study, no relationship was detected between EDSS and BMD. The inability to detect such a difference may be explained by all our patients being ambulatory and low EDSS values. In some studies were suggested inverse correlation disease duration and BMD $(16,23,24)$. In our study, there were no correlation BMD and other parameters.

In our study, osteoporosis and osteopenia were more frequent in men (46.6\% female versus 58.8\% males according to femur neck BMD and $37.83 \%$ female versus $64.7 \%$ males according to lumber BMD). And, the lumbar vertebrae $\mathrm{T}$ and $\mathrm{Z}$ scores of men were lower than women, which was statistically significant ( $\mathrm{p}$ : 0.003 and p: 0,00) (Table 2). In most studies on MS and osteoporosis, participants are mostly female patients. This may be due to the predominance of female patients in studies.

Vitamin D is a crucial vitamin in bone health. In addition, multiple studies were suggested that vitamin D have immunomodulatory effect and takes an important place in $\mathrm{T}$ cell homeostasis in the course of MS (25). In the our study, mean vitamin D levels of the whole study group was below the sufficiency level. In most studies concerning vitamin D in MS patients, vitamin D levels were observed to be lower in the patient group than in the control group $(12,22,23,25,26)$. In addition, we found no correlation between BMD and vitamin D levels. Similarly, there are studies that failed to find an relationship between vitamin D levels and BMD (21). However, only one study reported a significant relationship between vitamin $\mathrm{D}$ concentration and lumbar $\mathrm{T}$ and $\mathrm{Z}$ scores (22).

Osteocalcin is a hormone specific to osteoblast and plays a role in glucose homeostasis (27). Osteocalcin levels are a marker of bone formation. Osteocalcin levels were lower in MS patients compared to controls $(22,28)$. In our study, osteocalcin levels were found in normal range in $77,7 \%$ of patients (normal range: $2-21$ $\mathrm{ng} / \mathrm{ml}$ ).But, osteocalcin levels of osteoporosis patients were statistically higher than in others (p: 0,01). High osteocalcin levels are seen with increased bone remodeling and increased bone loss (29). Susanto et al. reported a significant inverse correlation between femoral neck BMD and serum osteocalcin (30). Terzi et al reported that, there was no significant relationship between osteocalcin and BMD (22).

High PTH levels were found in $31.5 \%$ of patients. Some studies were found that, the concentration of PTH was higher in the patient group (22). In our study, an inverse correlation was observed between PTH concentration and vitamin $\mathrm{D}$ concentration.

Certain limitations of the present study have to be acknowledged. We determined the study groups according to the total dose of IVMP received during the illness. Low disability scores of the patients, the low number of participants and lack of age and sex-matched healthy control group, are limitations of the study.

As a result, our study shows that BMD is decreased in MS patients. However, there is no correlation between cumulative CS and BMD dose in ambulatory MS patients. The presence of unknown factors other than CS dose may explain the difference between CS dose concentration and osteoporosis among MS patients.
Abbreviations
BMD - Bone mineral density
CS - Corticosteroid
DEXA - Dual energy X-ray absorptiometry
EDSS - Expanded Disability Status Scale
IVMP - Intravenous high-dose methylpredniso-
MS - Multiple sclerosis
RRMS - Relapsing-remitting MS lone

Conflict of Interests: The authors declare that there are no conflicts of interest related to this article.

Funding: None

\section{Licensing}

This work is licensed under a Creative Commons Attribution 4.0 International (CC BY 4.0) License. 


\title{
Sažetak
}

\section{ODNOS IZMEĐU MINERALNE GUSTINE KOSTIJU I KRATKOROČNE TERAPIJE VISOKIM DOZAMA KORTIKOSTEROIDA KOD PACIJENATA SA MULTIPLOM SKLEROZOM}

\author{
Sirinocak Bekdik Pinar, ${ }^{1}$ Eskut Neslihan, ${ }^{2}$ Sener Ufuk, ${ }^{3}$ Zorlu Yasar $^{3}$ \\ ${ }^{1}$ University of Health Science, Derince Training and Research Hospital, Department of Neurology, Kocaeli, Turkey \\ ${ }^{2}$ University of Health Science, Izmir Bozyaka Training and Research Hospital, Department of Neurology, Izmir, Turkey \\ ${ }^{3}$ University of Health Science, Izmir Tepecik Training and Research Hospital, Department of Neurology, Izmir, Turkey
}

Uvod: Izveštaji ranijih studija pokazuju da se osteoporoza i prelomi kostiju češće javljaju kod pacijenata sa multiplom sklerozom nego kod ostale populacije. Cilj ove studije je da istraži uticaj kratkoročne terapije visokim dozama kortikosteroida i druge faktore od uticaja na mineralnu gustinu kostiju kod pacijenata sa relapsno remitentnim oblikom multiple skleroze.

Materijal i Metode: Pedeset četiri pacijenta (37 ženskog i 17 muškog pola) sa relapsno remitentnim oblikom multiple skleroze, koji su ispunjavali McDonald-sove dijagnostičke kriterijume su bili uključeni u studiju. Merena je mineralna koštana gustina femoralne kosti i lumbalne kičme upotrebom DEXA metode (dual energy X-ray absorptiometry). Skala status proširene nesposobnosti, trajanje bolesti, broja napada, kumulativna doza kortikosteroida su beleženi. Serumski kalcijum, natrijum, fosfor, vitamin $\mathrm{D}$, parathormon $\mathrm{i}$ osteokalcin su mereni. Pacijenti su podeljeni u dve gru-

\section{REFERENCES}

1. Bazelier MT, vanStaa T, Uitdehaag BMJ, Cooper C, Leufkens HGM, Vestergaard $\mathrm{P}$, et al. The risk of fracture in patients with multiple sclerosis: The UK general practice research database. JBMR. 2011; 26(9): 2271-9.

2. Bhattacharya RK, Vaishnav N, Dubinsky RM. Is there an increased risk of thehipfracture in multiples clerosis? Analysis of the Nationwide in patient sample. J Multidiscip Health 2014; 7: 119-22.

3. Dobson R, Ramagopalan S, Giovannoni G. Bone health and multiple sclerosis. Mult Scler. 2012; 18(11): 1522-8.

4. Dong G, Zhang N, Wu Z, Liu Y, Wang L. Multiple sclerosis increases fracture risk: A meta-analysis. Biomed Res Int 2015; 2015: 650138. doi: 10.1155/2015/650138.

5. Gibson JC, Summers GD. Bone health in multiple sclerosis. Osteoporosis Int. 2011; 22(12): 2935-49.

6. Van Staa TP, Leufkens HGM, Cooper C. The epidemiology of corticosteroid-induced osteoporosis: a meta-analysis. Osteoporos Int 2002; 13(10): 777-87.

7. Smets I, VanDeun L, Bohyn C, vanPesch V, Vanopdenbosch L, Dive D, et al. Corticosteroids in the management of acute multiple sclerosis exacerbations. Acta Neurol Belg. 2017; 117(3): 623-33.

8. Sandhu SK, Hampson G. The pathogenesis, diagnosis, investigation and management of osteoporosis. J Clin Pathol. 2011; 64(12): 1042-50. pe: pacijente koji su primili najmanje $20 \mathrm{gr}$ metilprednizolona intravenski (Grupa I) i pacijente koji su primili manje od 20 gr metilprednizolona intravenski (Grupa II). Analizirali smo odnos između kumulativne doze kortikosteroida i svih parametara.

Rezultati: Osteopenia je bila prisutna kod $46,2 \%$ i osteoporoza kod 5,5\% ispitane populacije shodno mineralnoj gustini vrata butne kosti. Mineralna gustina butne kosti je bila značajno niža među pacijentima. Nije nađena korelacija između kumulativne doue kortikosteroida i mineralne gustine kostiju.

Zaključak: Niska mineralna gustina kostiju i osteoporoza su česte kod pacijenata sa multiplom sklerozom. Terapija visokim dozama kortikosteroida nije primarni uzrok osteoporoze kod pacijenata sa multiplom sklerozom.

Ključne reči: Multipla skleroza, mineralna gustina kostiju, vitamin D.

9. Ayatollahi A, Mohajeri-Tehrani MR, Nafissi S. Factors affecting bone mineral density in multiple sclerosis patients. Ir J Neurol. 2013; 12(1): 19-22.

10. Krela-Kazmierczak I, Michalak M, Szymczak-Tomczak A, £ykowska-Szuber L, Stawczyk-Eder K, Waszak K et al. Prevalence of osteoporosis and osteopenia in a population of patients with inflammatory bowel diseases from the Wielkopolska Region. Pol Arch Intern Med. 2018; 128(7-8): 447-54.

11. Kepczynska K, Zajda M, Lewandowski Z, Przedlacki J, Zakrzewska-Pniewska B. Bone metabolismand vitamin D status in patients with multiple sclerosis. Neurol Neurochir Pol. 2016; 50(4): 251-7.

12. Kirbas A, Kirbas S, Anlar O, Turkyilmaz AK, Cure $\mathrm{MC}$, Efe $\mathrm{H}$. Investigation of the relationship between vitamin D and bone mineral density in newly diagnosed multiples clerosis. Acta Neurol Belg. 2013; 113(1): 43-7.

13. Olsson A, Oturai DB, Sorensen PS, Oturai PS, Oturai AB. Short-term, high-dose glucocorticoid treatment does not contribute to reduced bone mineral density in patients with multiple sclerosis. Mult Scler. 2015; 21(12): 1557-65.

14. Tyblova M, Kalincik T, Zikan V, Havrdova E. Impaired ambulation and steroid therapy impact negatively on bone health in multiple sclerosis. Eur J Neurol. 2015; 22(4): 624-32.

15. Weinstock-Guttman B, Gallagher E, Baier M, Green L, Feichter J, Patrick K, et al. Risk of bone loss in men with multiple sclerosis. Mult Scler. 2004; 10(2); 170-5. 
16. Zengin Karahan S, Boz C, Kilic S, Can Usta N, Ozmenoglu M, Altunayoglu Cakmak V, et al. Lack of association between pulse steroid therapy and bone mineral density in patients with multiple sclerosis. Mult Scler Int. 2016; 2016: 5794910. doi: 10.1155/2016/5794910.

17. Zikan V, Tyblova M, Raska JR I, Havrdova E, Luchavova $\mathrm{M}$, Michalska $\mathrm{D}$, et al. Bone mineral density and body composition in men with multiple sclerosis chronically treated with low dose glucocorticoids. Physiol Res. 2012; 61(4): 405-17.

18. Zorzon M, Zivadinov R. Locatelli L, Giuntini D, Toncic M, Bosco A, et al. Long-term effects of intravenous high dose methylprednisolone pulses on bone mineral density in patients with multiple sclerosis. Eur J Neurol. 2005; 12(7): 550-6.

19. Clelant BT, Papanek P, Ingraham BA, Harkins A, Garnier-Villarreal M, Woo D, et al. Determinants of low bone mineral density in people with multiple sclerosis: Role of physical activity. Mult Scler Relat Disord. 2020; 38: 101864.doi: 10.1016/j.msard.2019.101864

20. Huang Z, Qi Y, Du S, Chen G, Yan W. BMI levels with MS bone mineral density levels in adults with multiple sclerosis: a meta-analysis. Int J Neurosci. 2015; 125(12): 904-12.

21. Triantafyllou N, Lambrinoudaki I, Thoda P, Andreadou E, Kararizou E, Alexandrou A, et al. Lack of association between vitamin $\mathrm{D}$ levelsand bone mineral density in patients with multiple sclerosis. J Neur Sci. 2012; 313 (1-2): 137-41.

22. Terzi T, Terzi M, Tander B, Cantürk F, Onar M. Changes in bone mineral densityand bone metabolism markers in pre- menopausal women with multiple sclerosis and the relationship to clinical variables. J Clin Neurosc. 2010; 17(10): 1260-4.

23. Coskun Benlidayi I, Basaran S, Evlice A, Erdem M, Demirkiran M. Prevalence and risk factors of low bone mineral density in patients with multiple sclerosis. Acta Clin Belg. 2015; 70(3): 188-92.

24. Tuzun S, Altintas A, Karacan I, Tangurek S, Saip S, Siva A. Bone status in multiple sclerosis: beyond corticosteroid. Mult Scler. 2003; 9(6): 600-4.

25. Correale J, Ysrraelit MC, Gaitan MI. Immunomodulatory effects of vitamin D in multiple sclerosis. Brain. 2009; 132(Pt5): 1146-60.

26. Ozgocmen S, Bulut S, Ilhan N, Gulkesen A, Ardicoglu O, Ozkan Y. Vitamin D deficiency and reduced bone mineral density in multiple sclerosis: effect of ambulatory status and functional capacity. J Bone Miner Metab. 2005; 23(4): 309-13.

27. Wei J, Karsenty G. An overview of the metabolic functions of osteocalcin. Rev Endoc Metab Disord. 2015; 16(2): 93-8.

28. Weinstock-Guttman B, Hong J, Santos R, Tamano-Blanco M, Badgett D, Patrick K, et al. Interferon-beta modulates bone-associated cytokines and osteoclast precursor activity in multiple sclerosis patients. Mult Scler. 2006; 12(5): $541-50$.

29. Agrawal BK, Jain V, Varshney A. Bone turn over markers in women can predict low bone mineral density. Int J Res Med Sci. 2015; 3(4): 876-9.

30. Susanto LTM. Serum osteocalcin and bone mineral density in postmenopausal women. Univ Med. 2011; 30(3): 155-61.

\section{Correspondence to/Autor za korespondenciju}

Neslihan Eskut, MD

ZafertepeMah 538. Sk no:1/13 Giritli Apt 6/17 Konak/İzmir

Telephone: +905054432205

fax :+90 (0232) 2619351

nespur@hotmail.com

https://orcid.org/0000-000-1882-8992 